\title{
Token-based blockchain financing and governance: A transaction cost economics approach
}

\author{
Lestaw Pietrewicz*
}

The paper presents a conceptual analysis of token-based blockchain financing and governance. Its aim is to explore governance attributes of tokens - a new financial instrument issued by blockchain startups - with a view to understanding deployment of tokens by blockchains and their design. Transaction cost economics (TCE) has been chosen as a theoretical perspective for the analysis. The paper extends the scope of TCE theory by applying it to the blockchain context, and to the study of the role and nature of tokens in particular. It is argued that blockchains aggregate and coordinate the contributions of a distributed network of peers using a set of rules encoded in the blockchain protocol, thus eliminating the need for a hierarchy and day-to-day management, and promising to reduce typical coordination problems plaguing hierarchical organizations. Tokens, and particularly utility tokens, are found to differ fundamentally from equity and debt in their financial and governance attributes as they aim to combine the low cost of the rule-based governance with added adaptability characteristic of equity-based governance. The analysis offers insights for both strategy and entrepreneurship research and practice as it helps identify industries most vulnerable to disruption by blockchains and inform promising blockchain-based business model designs.

Keywords: blockchain, corporate finance, corporate governance, token, transaction cost economics.

Submitted: 11.09.18 | Accepted: 10.12.18

\section{Tokeny w finansowaniu i zarządzaniu blockchainem: Perspektywa ekonomii kosztów transakcyjnych}

Artykut przedstawia koncepcyjna analize finansowania $i$ zarzadzania (governance) blockchainem $z$ wykorzystaniem tokenów. Celem opracowania jest zbadanie cech tokenów w zakresie governance, co ma stużý lepszemu zrozumieniu konstrukcji tokenów i ich wykorzystaniu $w$ blockchainach. Jako teoretyczna podstawe do analizy wybrano ekonomię kosztów transakcyjnych. Przeprowadzone badania wprowadzaja tę teorię na nowy obszar - blockchaina $i$ nowego instrumentu finansowego token. Badania te pozwalaja lepiej zrozumieć funkcjonowanie blockchaina - agregowanie $i$ koordynowanie wkładów podmiotów tworzacych społeczność blockchaina przy pomocy zasad zapisanych na protokole blockchaina, co eliminuje potrzebe utrzymywania biurokracji (jednostki hierarchicznej) i bieżacego zarządzania, umożliwiając obniżenie kosztów transakcyjnych. W pracy wykazano także zasadnicze różnice między tokenami ( $i$ w szczególności tokenami użytkowymi) a tradycyjnymi instrumentami

\footnotetext{
Lesław Pietrewicz - PhD, Institute of Economics, Polish Academy of Sciences.

Correspondence address: Institute of Economics, Polish Academy of Sciences, Staszic Palace, 72 Nowy Świat St., 00-330 Warsaw, e-mail: pietrewi@inepan.waw.pl.
} 
finansowymi - kapitatem wtasnym i dtugiem. Tokeny mają taczyć w sobie niski koszt governance opartego na zasadach $z$ wysokimi zdolnościami adaptacyjnymi charakterystycznymi dla bardziej zaangażowanych i elastycznych systemów opartych na kapitale wtasnym. Uzyskane wyniki niosa implikacje dla zarzadzania strategicznego i przedsiębiorczości, pomagajac identyfikować branże najbardziej narażone na niszczacy wptyw blockchainów i konstruować oparte na blockchainie modele biznesowe.

Słowa kluczowe: blockchain, ekonomia kosztów transakcyjnych, finanse przedsiębiorstwa, ład korporacyjny, token.

Nadesłany: 11.09.18 | Zaakceptowany do druku: 10.12.18

JEL: D21, D23, G32, G34

\section{Introduction}

Corporate finance and corporate governance are closely interrelated (e.g. Bender, 2013; Bolton and Scharfstein, 1998; Frederikslust, Ang and Sudarsanam, 2007; Gillan, 2006; Grossman and Hart, 1982; Hart, 1995; Jensen, 1986; Jensen and Meckling, 1976; Margaritis and Psillaki, 2010; Shleifer and Vishny, 1997; Sun, Ding and Guo, Li, 2016; Williamson, 1988). Corporate governance deals with the ways in which suppliers of finance to businesses assure themselves of getting a return on their investment (Shleifer and Vishny, 1997). It is done by linking capital in form of financial instruments with control rights given to their owners. As rights attached to various financial instruments differ, such instruments can be seen as different governance structures (Williamson, 1988), and corporate finance decisions to use one form of finance or another (e.g. debt or equity) have a bearing on optimal allocation of power in organizations (Hart, 1995) and can be used for economizing on transaction costs (Williamson, 1988).

Numerous studies have investigated the relation between corporate finance and corporate governance focusing on the tax, signaling, incentive, and bonding differences between debt and equity (Williamson, 1988). Typically, they take the aggregate, composite-capital setup view on corporate finance to study governance and performance implications of various ownership and capital structure arrangements.

Transaction cost economics (TCE thereafter) (e.g. Williamson 1975, 1985, 1996) goes further and regards debt and equity as governance structures rather than financial instruments (Williamson, 1988). Thus, it is most concerned with studying governance attributes of debt and equity taken separately, rather than in various proportions in capital structure. Similarly, it allows analyzing other financing arrangements, like leasing and leveraged buyouts (Ibid.). Such an approach has been selected for the present paper as it aims to explore governance attributes of tokens - a new financial instrument designed specifically for blockchain projects - with a view to understanding deployment of tokens by blockchains and their design. Such endeavor is instrumental in identifying transaction types and industries in which blockchains and tokens can support most disruptive business models.

The study of governance attributes of tokens seems to be highly relevant and timely undertaking. In 2017 the blockchain technology firmly established itself in the public awareness as a revolutionary new technology underpinning cryptocurrencies, while more and more startups experimented with other potentially disruptive applications across a range of functions and industries (Davidson, De Filippi and Potts, 2018). Blockchain, however, should be viewed as much more than simply a technological breakthrough. For Davidson, De Filippi and Potts (2016a, 2016b, 2018) and Piazza (2017), it provides a new form of economic coordination and entails a new form of governance.

We are now at an early stage of blockchain development (e.g. Higgison, Lorenz, Münstermann and Olesen, 2017; Pilkington, 2016), trying to make sense of its potential (Tapscott and Tapscott, 2016). The early stage of development implies immature governance. Blockchain founders are experimenting with both technology 
and governance issues. Tokens play a key role in such efforts as, on the one hand, selling them secures blockchain projects' financing, and, on the other, proper design of tokens, depending on a business model employed, is decisive for blockchain projects' success. Tokens are an integral part of many blockchain-based business models, and given their centrality and novelty they merit special attention. Better understanding of governance attributes of tokens can help advance their design, align blockchain governance and support more viable blockchain-based business models, as well as inform regulatory efforts.

Blockchain technology offers a new way of coordinating economic activity (Davidson et al., 2018; Piazza, 2017) and supports a new form of organization (e.g. Buterin, 2013, 2014; Hofer, 2018; Norta, 2016; Teutsch, Buterin and Brown, 2017), adding to the existing diversity. Therefore, blockchains should best be analyzed from the perspective of institutional economics (Davidson et al., 2018), equipped with concepts, tools and methodology to study institutions of economic coordination.

The present contribution assumes TCE (i.e. New Institutional Economics) as its theoretical perspective for several reasons. Firstly, the main novelty of blockchain consists in providing a new way of coordinating economic activities, which is the subject matter of TCE (e.g. Davidson et al., 2018; Menard, 2018; Williamson, 2002). Secondly, blockchains enable a new form of organization, and explanation of the phenomenon of diversity of organizational forms is often viewed as the main aim of TCE (e.g. Williamson, 1998). Thirdly, the choice of TCE is strongly supported by its applicability to corporate finance (Williamson, 1988). Tokens, being a financial instrument and an integral part of blockchain governance, can thus be studied in an integrated way. Fourthly, TCE studies organizations from the perspective of contracts and assumes transaction as the basic unit of analysis (Williamson, 1996; 2002). Since blockchain is an exchange (i.e. transaction) technology (as opposed to production technology) (Davidson et al., 2016a, 2016b) and owes its interest primarily to the potential to reduce transaction costs and spur competitive advantage (e.g. Catalini and Tucker, 2018; Conley, 2017), and, again, tokens are central to such endeavors (e.g. Bakos and Halaburda, 2018; Conley, 2017), TCE perspective again seems very useful. The latter aspect can be placed in a broader perspective of TCE approach as central to the fields of strategy and entrepreneurship (Foss, 2003; Gatignon and Gatignon, 2010; Michael, 2007; Nickerson, 2010). As transaction costs are essential aspects of creating, capturing and protecting value, TCE insights should be seen as necessary for adequately understanding the nature of strategic management (Foss, 2003). What follows is that the transaction cost approach to the study of blockchains can be seen as a basis for conducting strategic analyses of blockchains - as competing with one another and/or with other forms of governance. This, however, due to the complexity of the topic and space limits of the present paper, shall be a subject matter of another study.

The present paper presents a conceptual analysis of token-based blockchain financing and governance. It extends the scope of TCE theory by applying it to the blockchain context, and to the study of the role and nature of tokens in particular. It goes beyond the contributions of Davidson et al. (2016a, 2016b, 2018) and Piazza (2017) in assuming TCE approach to corporate finance and applying it to the study of tokens. Blockchain is interpreted here as a governance structure rather than just a technology, similarly, tokens are viewed as both financial and governance instruments.

The remaining part of the paper is structured as follows. The first section shortly introduces blockchains, indicating their main distinctive features and multiple conceptualizations. The next two sections develop the relation between corporate finance and corporate governance, reviewing the relevant TCE literature. Firstly, the basic tenets of the transaction cost economics are introduced, based on seminal contributions by Williamson, following which TCE logic is applied to corporate finance. Two subsequent sections concern blockchain financing and governance. In the fourth section the concept of blockchain is explored in relation to TCE extension to organizational forms beyond market and hierarchy. The fifth section explores the attributes and role of tokens in blockchain financing and governance. Concluding remarks follow. 


\section{What is blockchain}

In its most popular understanding, blockchain is a set of technologies developed around the concept of distributed ledgers, enabling secure peer-to-peer online transactions. The term, however, has been used to denote many aspects or layers (see Figure 1) of what constitutes blockchain in its widest sense (i.e. a governance structure), causing a lot of confusion. The resulting ambiguity implies that any reference to the term should be accompanied by a short definition (i.e. indication to a given layer of the meaning).

The term "blockchain", i.e. a chain of blocks, refers to a sequence of timestamped blocks of digital information stored on a decentralized database (the innermost layer on Figure 1). The decentralized database (ledger) using chains of blocks and related technologies for recording and storing information on a network of computers is also called blockchain (layer 2). Before being recorded in blocks, data (transactions or states) are verified using so-called consensus protocols, which replace centralized clearing settlement systems, making blockchains distributed settlement systems (Caytas, 2016; Kaminska, 2018) (layer 3). Blockchain is also a name given to blockchain technology-based distributed digital (online) platforms (Waters, 2017) (layer 4), i.e. a mode of organizing economic activities (Asadullah, Faik and Kankanhalli, 2015) adding to the existing variety (Zysman and Kenney, 2018), and a business model (e.g. Osterwalder and Pigneur, 2010) competing with central platforms (Waters, 2017), such as Amazon, Facebook or Airbnb. In this sense, blockchains enable users to interact directly with each other rather than through a central hub of the company which owns the central platform (Waters, 2017). Finally, blockchains are a new governance structure (Davidson et al., 2016a, 2016b, 2018) (layer 5), i.e. a new way of coordinating economic activities. Since blockchains' socalled consensus protocols offer a new way of producing consensus about facts, and such consensus is instrumental to economic coordination, blockchains can be seen as a revolutionary new institutional technology for economic coordination, i.e. a social technology (Nelson and Sampat, 2001). As such, blockchains compete with more established institutions of governance, such as firms, markets, governments, networks (Davidson et al., 2016a, 2016b,), profiding governance structure for blockchain-based applications (Davidson et al., 2018).

Figure 1. Conceptualizations of blockchain

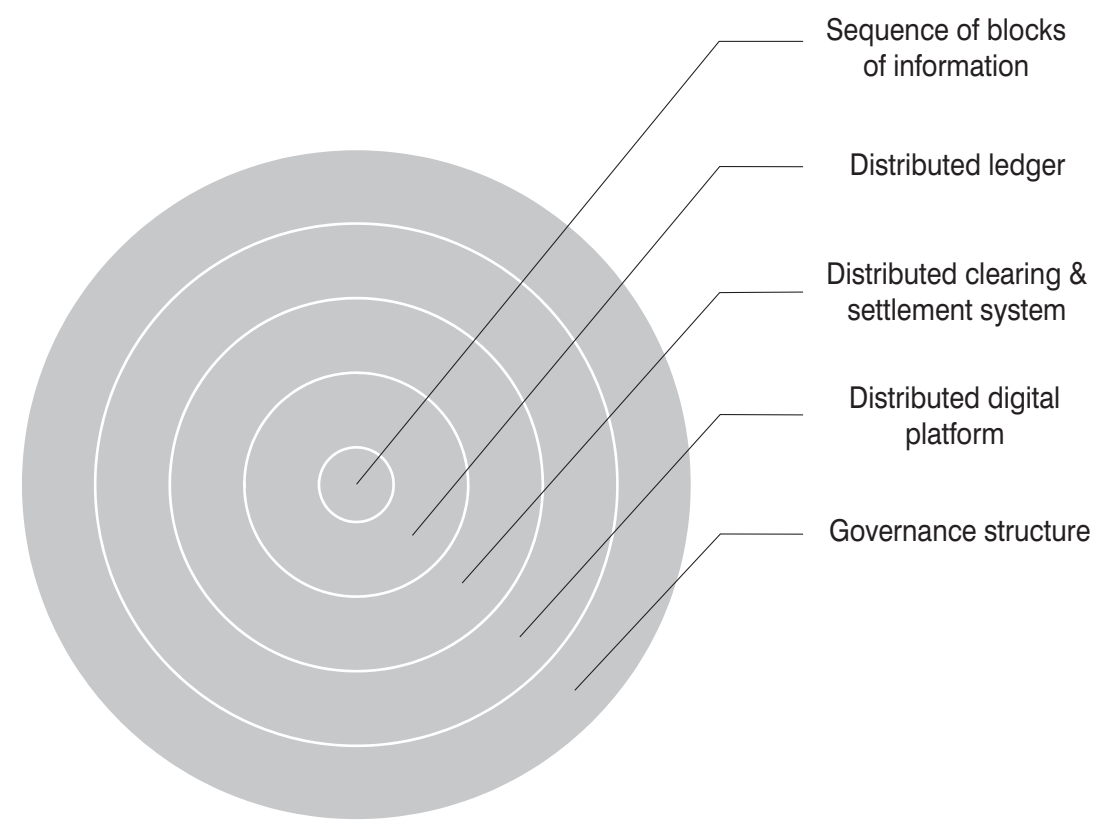

Source: own elaboration. 
While it is hard to explain what blockchain is, it is easier to say what blockchains do. They combine mathematical cryptography, open source software, computer networks and incentive mechanisms to produce consensus about the state of the world by verifying authenticity of transactions in a distributed way, without the involvement of trusted third parties (Davidson et al., 2016a). Each computer node in the network holds a copy of the ledger, so there is no single point of failure. Every piece of information is mathematically encrypted and added as a new "block" to the chain of historical records. Various consensus protocols are used to validate a new block with other participants before it can be added to the chain. This prevents fraud or double spending without requiring a central authority (Carson et al., 2018). Once created, the block (i.e. the information contained within) cannot be changed, giving blockchain the quality of immutability. Blockchains can be programmed with "smart contracts" - a set of conditions recorded on the blockchain protocol, so that transactions automatically trigger when the conditions are met (Carson et al., 2018). These qualities give the blockchain technology the business potential, which consists in streamlining operations, increasing accuracy of recordkeeping, boosting data security, assuring transparency of data, improving customer relationships, cutting costs and improving relationships (e.g. by reducing transaction times) (Terekhova, 2018; Yermack, 2017).

\section{Transaction cost economics}

TCE has its roots in the seminal work of Coase (1937), with Williamson (1975, 1985, 1996, 1998, and others) being the most notable contributor. TCE works from the concept of contract. According to it, any exchange problem can be interpreted as a contract, writing and fulfilling of which entail transaction costs, which are a universal measure of effectiveness of institutions of governance - markets, hierarchies, networks, governments and others (e.g. Williamson, 1985).

Transaction costs take the form of $e x$ ante and ex post costs (e.g. Williamson, 1985). The former are related to negotiating and writing contracts, while the latter include the governance structures' setup and running costs. Governance needs arise from and are related to incompleteness of contracts. If it was possible to draft comprehensive contracts at reasonable cost, further governance would be redundant. However, all contracts are by necessity incomplete, reflecting three factors: (1) in a complex and highly unpredictable world it is hard for people to think far ahead and to plan for all possible contingencies that may arise; (2) it is hard for the contracting parties to negotiate about these plans, and (3) it may be very difficult for the parties to write their plans down in such a way that, in case of a dispute, an outside authority could figure out what these plans actually mean and enforce them (Hart, 1995, p. 23). As a result, economic agents write incomplete contracts, i.e. contracts with ambiguities and missing provisions.

Incompleteness of contracts implies the existence of contractual hazards which induce transaction costs. TCE is concerned with identification, explication and mitigation of all forms of contractual hazards through governance (Williamson, 1996). Contractual hazards include: (1) bilateral dependency (resulting from asset specificity); (2) hazards that accrue to weak property rights; (3) measurement hazards; (4) intertemporal hazards (which can take the form of disequilibrium contracting, strategic abuse, etc.), and (5) hazards that accrue to weaknesses of institutional environment (Williamson, 1996).

Economic agents can align transactions with governance structures to lower transaction costs (e.g. Williamson, 1985; 1996). As achieving alignment requires understanding dimensions on which transactions and governance structures differ, TCE addresses the questions of what are the dimensions of transactions that present different hazards, and what attributes of governance structures mitigate hazards and at what cost? Then attributes of transactions need to be related to the costs and competencies of alternative modes of governance (Williamson, 1985; 1998).

Contractual hazards accrue to the following attributes of transactions: (1) the frequency of transactions, (2) the uncertainty to which transactions are subject, and (3) asset specificity (Williamson, 1985). The higher the frequency of interaction, the greater the uncertainty, and the greater the asset specificity, the greater the transac- 
tion costs. Of these three, asset specificity is accorded the most explanatory power, as it gives rise to bilateral dependency, anticipation of which reduces incentives to invest in relationship-specific assets out of the fear of expropriation at the renegotiation stage, strongly encouraging integration (Hart, 1995). In turn, critical dimensions of governance structures include: (1) form of contract law (court ordering or private ordering), (2) efficacy in autonomous and cooperative adaptation, (3) incentive intensity, and (4) administrative controls, resulting in different cost and competency profiles of governance structures (Williamson, 1998).

Organizational forms arise to meet contractual needs of transactions. Market is a simpler and less costly governance regime than hierarchy and therefore the preferred choice. Internal organization of transactions cannot replicate market procurement in incentive intensity and entails bureaucratic costs, hence the firm can be seen as an organizational form of last resort. Simple transactions can be carried out effectively in the market while more complex and thus costly governance structures are needed if contractual hazards complexify and the hierarchy's benefit of added coordination outweighs the cost of added bureaucracy and impossibility of selective intervention (Williamson, 1998). Market mode is the preferred governance structure if asset specificity is low, transactions less frequent, and uncertainty limited. The more specialized and less substitutable products are, the more they are suited for internal organization of transactions.

\section{Transaction cost approach to corporate finance}

Whereas the most typical example to which TCE is applied is the make or buy decision, or the problem of vertical integration in intermediate product markets, it can be applied to any issue that arises as or can be reformulated as a contracting problem, including contracts for capital between the firm and suppliers of finance (Williamson, 1988). In its basic formulation, it takes the form of a choice between debt and equity. Regarding debt and equity as different governance structures rather than as financial instruments, and distinguishing investment attributes of different projects results in the view of contractual relation to which standard TCE approach to the study of contracts can be applied.

While corporate finance scholars typically focus on the tax and bankruptcy, signaling (Ross, 1977), incentive and bonding (Jensen, 1986) differences between debt and equity, TCE is concerned primarily with the governance-structure attributes of debt and equity, where the former is the more market-like instrument and latter is more akin to hierarchy (Williamson, 1988). The discriminating use of debt and equity is thus regarded as a variation of the standard transaction-cost economizing theme of vertical integration (i.e. the make-or-buy decision), neatly fitting in Shleifer and Vishny's (1997) widely accepted formulation of the purpose of corporate governance as assuring the lowest possible cost of external capital for organizations in the long term.

The governance approach to corporate finance aims to determine what projects should be financed with what financial instruments, like debt and equity. To this aim, the project finance approach is adopted and the choice of debt or equity is seen as determined primarily by asset specificity (redeployability). Transaction cost reasoning supports the use of debt to finance redeployable assets, whereas nonredeployable assets should be financed with equity (Williamson, 1988).

In this approach, debt is viewed as a governance mechanism that works almost entirely out of rules (making debt "unforgiving"), and in the case of default, debtholders are entitled to pre-emptive claims to firm's assets. Equity allows much more discretion than debt (is more "forgiving"), equity holders are residual claimants with a contract for the firm's lifetime, entitled to vote for the board of directors in proportion to their share in equity. The board of directors monitors firm's managers and has the powers to decide on their compensation and to replace them, if judged appropriate. By giving the board of directors added control over management's actions ("intrusiveness of equity") and making equity more forgiving than debt, equity-based governance structure works to reduce the cost of capital for projects with low asset redeployability (Williamson, 1988).

For non-specific (i.e. redeployable) assets, the cost of debt is lower than equity considering that debt is a comparatively 
simple governance structure, with low setup costs and low running costs, as it is rule-governed. Equity is a much more complex governance mechanism, as it has higher setup cost and a greater discretion it allows comes at a cost of incentive compromising and politicking (Williamson, 1998).

As asset specificity increases, the cost of debt and equity grows, but the cost of debt grows more quickly. The reason is that, firstly, the value of pre-emptive claim decreases (as it offers limited protection); secondly, the benefits of closer oversight grow, and thirdly, debt, being a rule-based governance regime, can sometimes force firms to compromise value-creating initiatives or even to liquidate, when a more discretionary, and thus adaptable, governance regime of equity could be more supportive and value-adding (Williamson, 1988). Uncertainty, i.e. another aspect of contractual hazards, favors greater use of equity, as when added uncertainty pushes the firm into a maladapted state, rule-based governance regime experiences greater stress, and the more expensive regime of equity, supplanting rules with discretion, can be a source of added value (Williamson, 1998).

In short, TCE predicates that for moderately or highly redeployable assets, debt is a preferred governance regime, whereas equity is reserved for projects with high asset specificity and high adaptability needs (Williamson, 1988). Similarly, low uncertainty environment favors debt, whereas highly adaptable equity regime offers firms an edge in highly uncertain conditions.

\section{The rise and governance of blockchains}

Transaction cost economics provides a way of understanding the impact of new technologies on organizations and organizational forms. According to the theory, differences in technology give rise to different contractual hazards (Williamson, 1998). Hence, technological progress changes transaction cost structures, requiring adaptation in governance structures. Technology also enables changes in costs and competences of governance structures. With interactions, maladaptation is reduced and alignment restored. In the process, new organizational forms can arise.

Numerous scholars went beyond the original formulation of transacting prob- lem as the market and firm dichotomy to address, most notably, networks (e.g. Baker, Gibbons, Murphy, 2002; Blois, 1990; Economides, 1996; Jarillo, 1990), including joint ventures (Hennart, 1988) and entrepreneurial networks (Windsperger, Hendrikse, Cliquet, Ehrmann, 2018). Going beyond the conventional organizational forms of hierarchy and markets reflects the significant changes the scope of the firm has undergone, including an array of formal and informal alliances and partnerships. These unconventional organizational forms have been conceptualized as hybrids (Williamson, 1991; 1985), clans (Ouchi, 1980), and networks (Miles and Snow, 1986; Powell, 1990).

In recent years much attention has been given to the impact of digitization on transaction costs and organizational forms (e.g. Loebbecke and Picot, 2015; Teece, 2010). Digitization is argued to significantly lower transaction costs, both within and between organizations (Butler et al., 1997). The altered cost structure (substantial initial investment and negligible or low marginal costs) and nature of competition ("winnertakes-all" competition (e.g. Parker and Van Alstyne, 2005; Van Alstyne, Parker and Choudary, 2016)) put the issue of scalability (thus, the need to transact at scale) at the center stage. This, combined with lowering transaction costs with digital platforms (e.g. Lobel, 2018), has led to growing concentration in the internet (The Economist, 2017). The growing criticism of centralized digital platforms (Facebook, Google, Amazon, etc.) concerned claims of lacking transparency, allowing for single points of failure, censorship, abuse of power and other inefficiencies (e.g. Lange, 2017). Trusted intermediaries, however, were seen as indispensable to transact for economic agents who could not trust each other to transact online. The new blockchain technology promises to eliminate digital systems' need to have trusted parties (central intermediaries) who would guarantee transactions.

The transaction cost analysis of blockchains as an alternative to centralized digital platforms should cover their man governance components - smart contracts, transaction verification, and tokens. The former two will be considered in this section, while the role of tokens will be analyzed in the next one. 
Smart contracts are fragments of computer program encoded on a blockchain. They detail the conditions which, once met, trigger an automatic execution of contracts. Smart contracts can be simple or very complex, but the encoded conditions should be very precise and specific, leaving no room for interpretation and contestation (contracts are of binary nature). If the conditions detailed in the smart contract are not met, the transaction is not executed and the parties have no obligations to each other. As smart contracts are programmable, they can cover a variety of contracts and multiple provisions detailing parties' obligations in various potential states of the world. However, for more complex settings, they are not comprehensive, as writing a complete contract could be prohibitively expensive. If a specific state of the world is not provided for, the transaction will not be executed. As parties agree on using a given smart contract and, hence, underlying code, eventual litigations should be relatively simple (and cheap) as no human judgment or will was involved in "deciding" whether to execute the contract or not. Smart contracts should therefore be seen as strictly rule-based and not allowing discretion. The main idea is thus to economize on governance costs, leaving no room for exceptions and need for intervention. Not allowing for discretion implies lower transaction costs. Such benefits, however, come at the cost of adaptability. It follows that the governance structure of smart contracts needs to be complemented by other governance arrangements. When a need to improve the code is discovered, such proposal is voted on by token holders (more on this issue in the next section). From the governance point of view the use of selfexecuting smart contracts is remarkable as it eliminates the need for day-to-day management, freeing blockchains from possible human errors and agency problems, and reducing the risk of disputes between contracting parties.

The public, open code nature of smart contracts in public blockchains makes them attractive targets to hackers. The risk of bugs and attacks are forms of contractual hazards specific to the digital world. Whereas writing a bug-free smart contract is difficult, it is possible (although difficult) to formally verify them, i.e. to use methodology which allows to mathematically determine whether the program behaves according to a specification, which provides a better hazard mitigation than traditional approaches, like testing and peer reviews (Kasireddy, 2017).

The self-executable nature of smart contracts limits their viable applications. They can best be applied to routine transactions, i.e. those susceptible to standardization, and thus automation. By their nature, smart contracts are not a viable option for one-off complex contracts nor contracts for which conditions are hard to operationalize and encode. Since encoding a smart contract can be relatively expensive, and executing it should be very cheap (once technical obstacles are successfully dealt with), it makes most sense to apply them to frequent transactions. Uncertainty is another factor which can affect the legitimacy of smart contracts. Increased uncertainty elicits maladaptation. Once created (encoded) and marketed, smart contract cannot be easily changed and may require costly and time-consuming negotiations by token holders (tokens typically carry voting rights). Thus, uncertainty increases transaction costs and reduces the utility of smart contracts, particularly due to their binary nature. Finally, weakness of institutional environment increases the legitimacy of smart contracts as they can partially substitute for state regulation, thus mitigating hazards that accrue to weak institutional environment.

In blockchains, transactions are verified using so-called consensus protocols. There are two main types of such protocols: proof of work (PoW) (e.g. Nakamoto, 2008; Pilkington, 2016) and proof of stake (PoS) (e.g. Saleh, 2018). Both are consensus algorithms providing a way to achieve distributed consensus. In PoW consensus is achieved using information validation in open competition. Anybody with proper software and hardware can become a network node and participate in the competition, and the winning party is rewarded with tokens. Excessive energy consumption, however, makes this approach unsustainable. In PoS, those who want to participate have to commit their tokens, and business is granted in proportion to committed tokens. In both consensus regimes other nodes play the role of confirming calculations of the winning node and storing copies of the ledger (each node stores a copy). 
Consensus protocols are also relevant for governance in the context of asset specificity. In the proof of work consensus specialized hardware has a strong advantage. In 2013, devices called application-specific integrated circuits (ASICs) were designed solely for the purpose of mining Bitcoin, providing a 10-50-fold rise in efficiency and making mining with a regular computer's CPU and GPU unprofitable (Kasireddy, 2017). An alternative PoS consensus eliminates the need for specialized (i.e. nonredeployable) hardware.

\section{Financial and governance role of tokens}

Tokens are a digital currency native to a given blockchain. They play multiple functions in blockchain financing and governance. Firstly, they are sold in so-called Initial Coin Offerings (ICOs), providing finance to blockchain startups. Secondly, as they act as the internal currency of a blockchain, they can be used to pay for blockchain's services and can be rewarded for work accomplished (succeeding in computations and adding a block of data). Thirdly, in PoS consensus mechanism they play an additional role of allocating business (orders to verify transactions).
Fourthly, they enable the new organizational form of so-called distributed autonomous organizations (DAOs) (Buterin, 2013; 2014), or "community structures" (Teutsch et al., 2017), by being instrumental in distributing value to holders. Fifthly, they give holders voting rights when protocol updates are deemed necessary. Finally, as token value is related to functionality (usefulness) of a given blockchain, they align all participants' interests to make the network more valuable. In general terms, designing tokens requires understanding where the token can be used (how many end points the token is meant to hit, how it travels between them - does it circulate between participants within the network, is it exchanged between two or more parties, or is it spent on a service and then "destroyed"), and for how many use cases (as protocol tokens can power many use cases within a single or several protocol layers (Autonomous NEXT, 2018). Designing blockchain governance involves modeling participant behavior inside the network and how tokens mediate in interactions. The situation is thus much more complex than in the case of traditional financial instruments and firms. The summary characteristics of token-mediated blockchain financing and governance is given in Figure 2.

Figure 2. Financing and governance roles of tokens

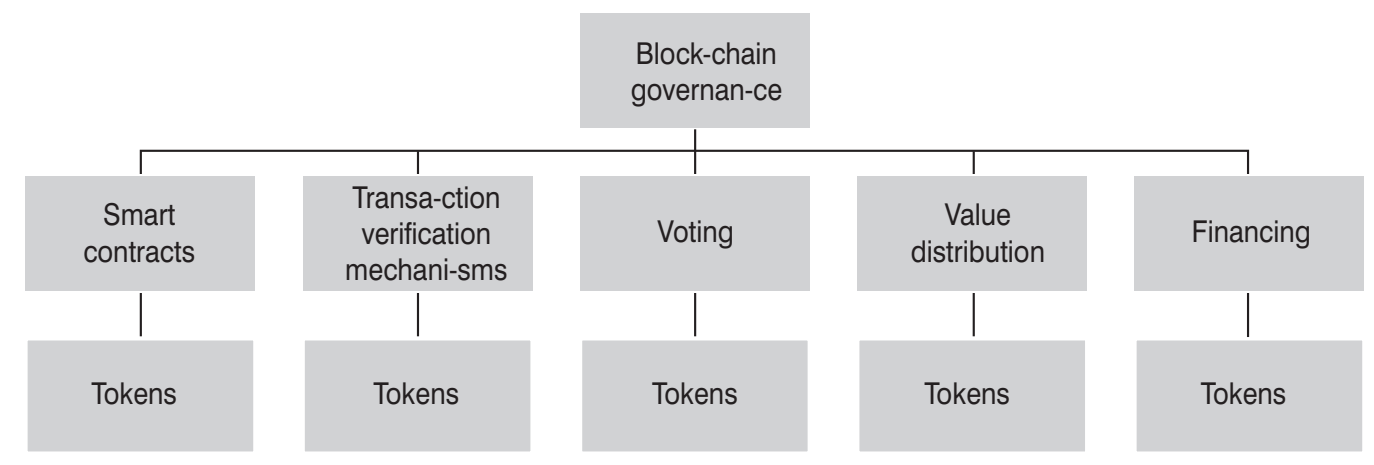

Source: own elaboration.

Blockchain project financing and governance design is a major challenge for blockchains adoption at scale. Great majority of blockchain projects are developed by startups seeking financing at the proof of concept stage. Tokens are a dedicated new form of finance, allowing to raise funds by previously "unfundable" open source software projects (Srinivasan, 2017). There are various types of tokens (e.g. Pietrewicz, 2018), and relevant taxonomies are in flux, reflecting the nascent stage of development of this new instrument, indeterminate legal status in many jurisdictions, changing market sentiment and directions of blockchain technology evolution. Entrepreneurs are experimenting with blockchain protocol and applications development, and 
with future network governance rules and design of tokens.

For simplicity reasons only one type of token - utility token - is considered in the present contribution. This choice is motivated by this token type being arguably the most innovative in terms of both financial and governance attributes, and, at least till recently, also the most popular. It can play the double function of a means of payment for the network services and a reward for work rendered, i.e. transaction verification. Thus, utility tokens are required to access a protocol and pay for the service. The same token is used to incentivize computing power holders to contribute work to a given blockchain network by using that power ("hashpower") to verify transactions.

2017 was a landmark year for blockchain startups seeking external financing in Initial Coin Offerings (ICOs), that is token issuances. According to Coinschedule.com data, blockchain startups raised over $\$ 3.7$ billion in ICOs in 2017, an almost 40-fold increase over the previous year, dwarfing other sources of finance for blockchain startups. One advantage of token issuances is democratizing finance. The traditional model of tech startup financing effectively keeps small investors from participating financially in the fortunes of promising new ventures. ICOs allow individuals to allocate even small amounts of money to an ICO, thus dramatically reducing entry barriers to participate financially in the successes of the startup sector (Pietrewicz, 2018) and reducing the cost of finance for blockchain startups. At the same time, ICOs have made it possible for these startups to raise far larger amounts than startups can usually tap (Waters, 2017).

The large scale of initial financing have both merits and drawbacks. Starting with the latter, although part of the proceeds from ICOs is typically intended for further development of software underpinning blockchain project and decentralized infrastructure, very large sums of money at developer team disposal can produce slack and even provoke dishonesty as all too many cases have shown. One way to go about this hazard would be to make funds available to developer team in tranches, after reaching predetermined milestones. Large scale of ICOs is, however, primarily motivated by other governance considerations. Blockchains, to be feasible, need to reach a critical mass. The major advantage of blockchains relative to other arrangements is the network effect (Carson et al., 2018). Tokens are critical to growing the scale of the network as their key role is to incentivize the use of a given blockchain's services. In simplest terms, prospective users are more likely to use the service of a given blockchain if they hold its tokens; as their custom supports the blockchain, the value of tokens they hold should increase. Similarly, prospective nodes are more likely to commit resources to a given network if they hold its tokens, since their serving as a node increases the value of the blockchain to users, and that should translate into increasing the value of their tokens. Potential benefits of using blockchains for transacting increase with the size of the network, as more nodes increase the security of transactions and larger number of trades should reduce transaction costs, once the critical technical problem of scalability is resolved. What follows is that token issuances should be motivated primarily by effecting network effect, for which purpose tokens issued in ICOs should find themselves in the hands of future blockchain's users and prospective network nodes. Hence, the strictly financial goal of maximizing the proceeds form ICOs should be subordinated to corporate governance goal of incentivizing future customers. Thus, the offer must be properly structured and priced, including so-called pre-ICOs in which tokens can be offered to preselected entities at steep discounts.

As technology advances, regulations and competitive pressures change, smart contracts may need to be renegotiated. Such renegotiation, however, is not carried out on a case-to-case basis, but concerns the rules to be encoded in new smart contracts which are to replace the old ones. Proposed changes are decided upon democratically, with votes distributed between token holders in proportion to their possessions. As the rationale behind developing smart contracts concerns primarily reducing transaction costs (e.g. by speeding up transactions and ridding of the need to interpret states of the world not explicitly addressed), the use of tokens to balance the interests of parties to a transaction (avoiding expropriation) can streamline the upgrading process. Blockchain networks effectively leave control in the hands of token holders, and 
not the central hub of the code developer. Tokens give users control of the network and let them profit from its success.

Finally, utility tokens do not hold rights to cashflow, profits nor liquidation money of any entity. Rather, token holders gain product value by being able to spend their tokens or they can exchange them for other tokens or fiat money on dedicated platforms (Deloitte, 2017). Giving rights to product value rather than a company's cash flow or profit is a governance experiment that requires repeated verification.

\section{Conclusions}

The present contribution focused on exploring token-based blockchain financing and governance using the conceptual apparatus of transaction cost economics. It portrayed blockchain as a new institution of governance (a mechanism of governance). Tokens (utility tokens) were found to differ fundamentally from equity and debt in their financial and governance attributes.

The goal of embedding incentives into digital services is to propel the network effect and give organizations (networks), deploying them a competitive advantage over centralized platform networks. Prospective users should prefer to choose to commit their custom to blockchains rather than centralized platforms if the former offer them a share in benefits from their growth. A well designed utility token should not only incentivize adoption, but also work towards aligning interests of all its holders. Therefore, allocating them to relevant parties at the ICOs stage should override the purely financial goal of maximizing proceeds from the issuance.

Blockchains aggregate and coordinate the contributions of a distributed network of peers using a set of rules encoded in the blockchain protocol, thus eliminating the need for a central authority and day-to-day management, and promising to reduce typical coordination problems plaguing hierarchical organizations, including large overheads, human error and agency problems, and thus dramatically reducing transaction costs. However, thanks to their design, blockchains can rely on cooperative adaptation and its advantages.

Utility tokens aim to combine the low cost of the rule-based governance with added adaptability typical of equity-based governance. Combining their role in smart contracts execution with the role in consensus mechanism is the chosen approach. The bigger picture is that traditional stakeholder roles combine, overlap and merge in blockchains. With tokens, investors can be expected to assume roles beyond the traditional rights and responsibilities of investors, to include those of nodes, validators, customers and dispute resolvers. It can be argued that the fusion of these roles and the resulting need to reimagine and redefine the relationships and roles of parties to transactions make blockchain an experiment in governance and organization.

Finally, the analysis implies that blockchain and token potential in various industries should depend on the structure of contractual hazards and attributes of transaction costs. In a recent study Liu and Tsyvinski (2018) identified potential winners and losers from the adoption of the blockchain technology and related cryptocurrencies. By regressing each industry's stock returns on main cryptocurrencies returns and the excess stock market returns, they found positive correlations, for example for consumer goods, healthcare, and negative for asset trade (finance) industry. Given the lack of theory behind, such findings should be approached with great caution. Transaction cost economics offer a theoretical background on which to develop propositions concerning the prospects of blockchain and tokens in each industry and to test them in comparative settings.

\section{References}

Asadullah, A., Faik, I. and Kankanhalli, A. (2018). Digital Platforms: A Review and Future Directions. PACIS 2018 Proceedings, 248, https://aisel.aisnet. org/pacis2018/248/ (28.11.2018).

Autonomous NEXT (2018). Crypto Utopia. Autonomous NEXT Report, July 2018.

Baker, G., Gibbons, R. and Murphy, K. (2002). Relational contracts and the theory of the firm. Quarterly Journal of Economics, 117(1), 39-83, https://doi.org/10.1162/003355302753399445

Bakos, Y. and Halaburda, H. (2018). The Role of Cryptographic Tokens and ICOs in Fostering Platform Adoption, http://dx.doi.org/10.2139/ssrn.3207777

Bender, R. (2013). Corporate Governance and Financial Strategy. In: R. Bender, Corporate Financial Strategy (4th ed.). London-New York: Routledge. 
Blois, K. (1990). Transaction costs and networks. Strategic Management Journal, 11(6), 493-496, https://doi.org/10.1002/smj.4250110607

Bolton, P. and Scharfstein, D. (1998). Corporate Finance, the Theory of the Firm, and Organizations. Journal of Economic Perspectives, 12(4), 95-114.

Buterin, V. (2013). Bootstrapping A Decentralized Autonomous Corporation: Part I. Bitcoin Magazine, https://bitcoinmagazine.com/articles/ bootstrapping-a-decentralized-autonomous-corporation-part-i-1379644274/ (2018.10.25).

Buterin, V. (2014). DAOs, DACs, DAS and More: An Incomplete Terminology Guide, https://blog. ethereum.org/2014/05/06/daos-dacs-das-and-morean-incomplete-terminology-guide/ (21.11.2018).

Butler, T., Hall, A., Hanna, L., Mendonca, B., Auguste, Manyika, J. and Sahay, A. (1997). A revolution in interaction. The McKinsey Quarterly, 1/1997, 5-23.

Carson, B., Romanelli, G., Walsh, P. and Zhumaev, A. (2018). Blockchain beyond the hype: What is the strategic business value? McKinsey \& Company, June 2018, https://www.mckinsey.com/ business-functions/digital-mckinsey/our-insights/ blockchain-beyond-the-hype-what-is-the-strategicbusiness-value

Catalini, C. and Tucker, C. (2018). Antitrust and Costless Verification: An Optimistic and a Pessimistic View of the Implications of Blockchain Technology. MIT Sloan Research Paper No 5523-18, ide.mit.edu/sites/default/files/publications/SSRNid3199453.pdf (15.11.2018).

Caytas, J. (2016). Developing Blockchain Real-Time Clearing and Settlement in the EU, U.S., and Globally, https://ssrn.com/abstract $=2807675$

Coase, R.H. (1937). The nature of the firm. Economica , 4, 386-405, doi.org/10.1111/j.1468-0335.1937. tb00002.x

Conley, J. (2017). Blockchain and the Economics of Crypto-tokens and Initial Coin Offerings. Vanderbilt University Department of Economics Working Papers, VUECON-17-00008, http://www.accessecon.com/Pubs/VUECON/VUECON-17-00008. pdf (26.11.2018).

Davidson, S., De Filippi, P. and Potts, J. (2016a). Disrupting governance: The new institutional economics of distributd ledger technology, http://dx.doi. org/10.2139/ssrn.2811995

Davidson, S., De Filippi, P. and Potts, J. (2016b). Economics of Blockchain, http://dx.doi.org/10.2139/ ssrn. 2744751

Davidson, S., De Filippi, P. and Potts, J. (2018). Blockchains and the economic institutions of capitalism. Journal of Institutional Economics, 14(4), 639-658, https://doi.org/10.1017/ S1744137417000200
Deloitte (2017). Initial coin offering. A new paradigm, https://www2.deloitte.com/us/en/pages/consulting/articles/initial-coin-offering-a-new-paradigm.html\# (01.02.2018).

Economides, N. (1996). The economics of networks. International Journal of Industrial Organization, 14(6), 673-699, https://doi.org/10.1016/01677187(96)01015-6

Foss, N. (2003). The Strategic Management and Transaction Cost Nexus: Past Debates, Central Questions, and Future Research Possibilities. Strategic Organization, 1(2), 139-169, https://doi. org/10.1177/1476127003001002304

Frederikslust, van R., Ang, J. and Sudarsanam, P. (eds.) (2007). Corporate Governance and Corpoate Finance: A European perspective. New York: Routledge.

Gatignon, A. and Gatignon, H. (2010). Erin Anderson and the Path Breaking Work of TCE in New Areas of Business Research: Transaction Costs in Action. Journal of Retailing, 86(3), 232-247.

Gillan, S. (2006). Recent Developments in Corporate Governance: An Overview. Journal of Corporate Finance, 12(3), 381-402, https://doi. org/10.1016/j.jcorpfin.2005.11.002

Grossman, S. and Hart, O. (1982). Corporate financial structure and managerial incentives. In: J. McCall (ed.), The Economics of Information and Uncertainty. Chicago: University of Chicago Press.

Hart, O. (1995). Firms, contracts, and financial structure. Oxford and New York: Oxford University Press.

Hennart, J. (1988). A transaction cost theory of equity joint ventures. Strategic Management Journal, 9(4), 361-374.

Higgison, M., Lorenz, J., Münstermann, B. and Olesen, P. (2017). The promise of blockchain. https://www.mckinsey.com/industries/financialservices/our-insights/the-promise-of-blockchain (2018.11.20).

Hofer, P. (2018). The DAO Case - Block Chain Technology Based Knowledge Intensive Business Models. In: K. North, R. Maier and O. Haas (eds.), Knowledge Management in Digital Change. Progress in IS. Springer, Cham, https://doi.org/10.1007/9783-319-73546-7_22

Jarillo, J. (1990). Comments on 'Transaction costs and networks'. Strategic Management Journal, 11, 497-499, https://doi.org/10.1002/smj.4250110608

Jensen, M. (1986). Agency costs of free cash flow, corporate finance, and takeovers. American Economic Review, 76(2), 323-329.

Jensen, M. and Meckling, W. (1976). Theory of the firm: managerial behavior, agency costs, and capital structure. Journal of Financial Economics 3(4), 305360, https://doi.org/10.1016/0304-405X(76)90026-X 
Kaminska, I. (2018). Truth and fiction in blockchain's brave new world, https://www.ft.com/ content/1858c8a0-efa7-11e7-ac08-07c3086a2625 (5.01.2018).

Kasireddy, P. (2017). Fundamental challenges with public blockchains, https://medium.com/@preethikasireddy/fundamental-challenges-with-publicblockchains-253c800e9428 (12.06.2018).

Lange, A. (2017). Mapping the decentralized world of tomorrow, https://medium.com/birds-view/ mapping-the-decentralized-world-of-tomorrow5bf36b973203 (10.06.2018).

Liu, Y. and Tsyvinski, A. (2018). Risk and Returns of Cryptocurrency. SSRN Working Paper, doi. org $/ 10.2139 /$ ssrn.3226952

Lobel, O. (2018). Coase and the Platform Economy. In: N. Davidson, M. Finck and J. Infranca (eds.), The Cambridge University Press Sharing Economy Handbook. Cambridge University Press

Loebbecke, C. and Picot, A. (2015). Reflections on societal and business model transformation arising from digitization and big data analytics: A research agenda. Journal of Strategic Information Systems, 24(3), 149-157, https://doi.org/10.1016/j. jsis.2015.08.002

Margaritis, D. and Psillaki, M. (2010). Capital structure, equity ownership and firm performance. Journal of Banking and Finance, 34(3), 621-632, doi.org/10.1016/j.jbankfin.2009.08.023

Menard, C. (2018). Research frontiers of new institutional economics. RAUSP Management Journal, 53(1), 3-10.

Michael, S. (2007). Transaction cost entrepreneurship. Journal of Business Venturing, 22(3), 412-426, https://doi.org/10.1016/j.jbusvent.2006.04.005

Miles, R. and Snow, C. (1986). Organization: new concepts for new forms. California Management Review, 28(3), 62-73, https://doi.org/10.2307/41165202

Nakamoto, S. (2008). A peer-to-peer electronic cash system. https://bitcoin.org/bitcoin.pdf (20.11.2018).

Nickerson, J. (2010). Oliver Williamson and His Impact in the Field of Strategic Management. Journal of Retailing, 86(3), 270-276, https:/doi. org/10.1016/j.jretai.2010.07.007

Norta, A. (2015). Creation of Smart-Contracting Collaborations for Decentralized Autonomous Organizations. In: R. Matulevičius and M. Dumas (eds.), Perspectives in Business Informatics Research. BIR 2015. Lecture Notes in Business Information Processing, vol. 229. Springer, Cham, 3-17, https:// doi.org/10.1007/978-3-319-21915-8_1

Osterwalder, A. and Pigneur, Y. (2010). Business Model Generation: A Handbook for Visionaries, Game Changers, and Challengers. John Wiley \& Sons.
Ouchi, W. (1980). Markets, bureaucracies, and clans. Administrative Science Quarterly, 25(1), 120-142.

Parker, G. and Van Alstyne, M. (2005). Two-Sided Network Effects: A theory of Information Product Design. Management Science, 51(10), https://doi. org/10.1287/mnsc.1050.0400

Piazza, F. (2017). Bitcoin and the Blockchain as Possible Corporate Governance Tools: Strengths and Weaknesses. Penn State Journal of Law \& International Affairs, 5(2), 262-301.

Pietrewicz, L. (2018). Emerging trends in entrepreneurial finance: The rise of ICOs. Studia i Materiaty. Wydziat Zarzadzania Uniwersytetu Warszawskiego, 2/2018.

Pilkington, M. (2016). Blockchain Technology: Principles and Applications. In: F. Olleros and M. Zhedu (red.), Research Handbook on Digital Transformations. Edward Elgar.

Powell, W. (1990). Neither market nor hierarchy: network forms of organization. Research in Organizational Behavior, 12, 295-336.

Ross, S. (1977). The Determination of Financial Structure: The Incentive Signaling Approach. Bell Journal of Economics, 8(1), 23-40, https://doi. org/10.2307/3003485

Saleh, F. (2018). Blockchain Without Waste: Proofof-Stake, http://dx.doi.org/10.2139/ssrn.3183935

Shleifer, A. and Vishny, R. (1997) A Survey of Corporate Governance. The Journal of Finance, 52(2), 737-783, https://doi.org/10.1111/j.1540-6261.1997. tb04820.x

Srinivasan, B. (2017). Thoughts on Tokens. https:// news.earn.com/thoughts-on-tokens-436109aabcbe (15.09.2017).

Sun, J., Ding, L., Guo, J. and Li, Y. (2016). Ownership, capital structure and financing decision: Evidence from the UK. The British Accounting Review, 48(4), 448-463, https://doi.org/10.1016/j. bar.2015.04.001

Tapscott, D. and Tapscott, A. (2016). Blockchain Revolution: How the Technology Behind Bitcoin Is Changing Money, Business, and the World. New York: Penguin.

Teece, D. (2010). Forward Integration and Innovation: Transaction Costs and Beyond. Journal of Retailing, 86(3), 277-283, https://doi.org/10.1016/j. jretai.2010.07.013

Terekhova, M. (2018). Beyond Bitcoin. BI Intelligence Report, March 2018.

Teutsch, J., Buterin, V. and Brown, C. (2017). Interactive coin offerings, https://people.cs.uchicago. edu/ teutsch/papers/ico.pdf

The Economist (2017). Regulating the internet giants: The world's most valuable resource is no longer oil, but data, 6 May 2017, https:/www.econ- 
omist.com/news/leaders/21721656-data-economydemands-new-approach-antitrust-rules-worldsmost-valuable-resource (15.06.2018).

Van Alstyne, B., Parker, G. and Choudary, S. (2016). Pipelines, Platforms, and the New Rules of Strategy. Harvard Business Review, April, 2-9.

Waters, R. (2017). To coin a craze: Silicon Valley's cryptocurrency boom, https://www.ft.com/ content/2b0d8926-96d9-11e7-b83c-9588e51488a0 (13.09.2017).

Williamson, O. (1975). Markets and Hierarchies: Analysis and Antitrust Implications. A Study in the Economics of Internal Organization. New York: The Free Press.

Williamson, O. (1985). The Economic Institutions of Capitalism: Firms, Markets, Relational Contracting. New York: The Free Press.

Williamson, O. (1988). Corporate Finance and Corporate Governance. Journal of Finance, 43(3), 567-591, https://doi.org/10.2307/2328184

Williamson, O. (1991). Comparative Economic Organization: The Analysis of Discrete Structural Alternatives. Administrative Science Quarterly, 36(2), 269-296, doi.org/10.2307/2393356
Williamson, O. (1996) The mechanisms of governance. Oxford and New York: Oxford University Press.

Williamson, O. (1998). Transaction Cost Economics: How It Works, Where It is Headed. De Economist, 146(1), 23-58, https://doi. org/10.1023/A:1003263908567

Williamson, O. (2002). The Theory of the Firm as Governance Structure: From Choice to Contract. Journal of Economic Perspectives, 16(3), 171-195.

Windsperger, J. Hendrikse, G. Cliquet, G. and Ehrmann, T. (2018). Governance and strategy of entrepreneurial networks: an introduction. Small Business Economics, 50(4), 671-676, https://doi. org/10.1007/s11187-017-9888-0

Yermack, D. (2017). Corporate Governance and Blockchains. Review of Finance, 21(1), 7-31, https:// doi.org/10.1093/rof/rfw074.

Zysman, M. and Kenney, M. (2015). Choosing a Future in the Platform Economy: The Implications and Consequences of Digital Platforms. Kauffman Foundation New Entrepreneurial Growth Conference, Amelia Island Florida, http://www.brie.berkeley.edu/wp-content/uploads/2015/02/PlatformEconomy2DistributeJune21.pdf (12.05.2017). 